\title{
Mosty w architekturze Bilbao
}

\section{Sławomir Karaś}

\author{
Politechnika Lubelska, Wydziat Budownictwa i Architektury, Katedra Dróg i Mostów
}

\begin{abstract}
Streszczenie: Artykuł dotyczy rewitalizacji post-przemysłowego miasta Bilbao. Rewitalizację przeprowadzono dzięki nowoczesnym obiektom architektonicznym w symbiozie z interesującą historyczna zabudową miejską. Punktem zwrotnym była lokalizacja budynku zaprojektowanego przez Franka Gehry'ego, muzeum sztuki Guggenheim Bilbao, i towarzyszących mu obiektów w centrum miasta. Bilbao jest położone wzdłuż rzeki Nervion. Nowe mosty w Bilbao są interesujące przez swą nowoczesność formy. Sąsiadują z mostami historycznymi w sposób komplementarny. Ożywienie turystyczne ściąga do miasta miliony turystów, ale także kolejnych znanych architektów, którzy chcą tu pozostawić swój ślad. Jednym z nich jest Santiago Calatrawa, który wybudował pionierską technicznie i oryginalną architektonicznie kładkę dla pieszych Zubizuri Zubia. W artykule przedstawiono kilka ciekawych mostów z innych miast Kraju Basków.
\end{abstract}

\section{Wstęp}

Bilbao, (bask. Bilbo), największe miasto Kraju Basków (Vizcaya), jest usytuowane w głębokiej dolinie rzeki Nervion. Zabudowania uliczne, kwartałowe. Na stokach doliny tworzą zwarty krajobraz miejski. Charakterystyczny jest brak zabudowy niskich domów wolnostojących, tak w starej zabytkowej części miasta jak i w nowych quasi-satelickich dzielnicach odległych od centrum.

Układ miejski jest niewiele zmodyfikowanym schematem miasta z okresu jego przemysłowej świetności. Na przełomie XIX i XX wieku w okolicach Bilbao wydobywano i przetwarzano na skalę przemysłową rudy żelaza i metali nieżelaznych. Rozwój przemysłu metalurgicznego, stoczniowego określa się okresem rewolucji przemysłowej. Usytuowanie, głównie na lewym brzegu Nerwionu portu ciągnącego się od zatoki biskajskiej do centrum miasta dodatkowo stymulowało rozwój kapitalizmu, który objawiał się powstawaniem banków, teatrów, giełdy, budową linii kolejowych, rozwojem kontaktów handlowych w tym przede wszystkim z Anglią. Upadek przemysłu pozostawił miasto bez koncepcji na dalszy rozwój, raczej można mówić o upadku, którego elementy są dalej widoczne, jako martwe i zniszczone tereny poprzemysłowe w górnym biegu Nervionu. W czasie dyktatury frankistowskiej cały Kraj Basków był postrzegany, jako rodzaj opozycji, której korzenie tkwiły w krzywdach doznanych przez republikański region doświadczony licznymi zniszczeniami w czasie wojny domowej. Los Gerniki jest przykładem barbarzyńskich nalotów bombowych lotnictwa niemieckiego i włoskiego, które doprowadziło do zniszczenia zabudowy miejskiej w $85 \%$. Wyrazem tych dramatycznych wydarzeń jest obraz Picassa Guernica eksponowany w Centro de Arte Reina Sofía w Madrycie. Natomiast w miejscowości Gernika znajduje się muzeum tego obrazu, którego treść jest niestety dalej współcześnie aktualna.

W dniu 1 stycznia 1986 r. Hiszpania stała się członkiem Unii Europejskiej. Ten moment można określić, jako punkt zwrotny we współczesnej historii półwyspu Iberyjskiego.

W 1991 r. rząd Kraju Basków podjął współpracę z zarządem fundacji Solomona R. Guggenheima, proponując budowę muzeum w Bilbao. Projektowanie budynku rozpoczęto w roku 1994, a zakończenie nastąpiło w 1997 r., przez otwarcie hiszpańskiego muzeum sztuki nowoczesnej.

Projektant muzeum, amerykański architekt Frank Gehry, miał pełną świadomość przyszłej roli rewitalizacyjnej budynku muzeum i muzeum w całości. Świadczy o tym dostępna w sieci www jego niekonwencjonalna wypowiedź podczas przyjęcia nagrody Premios Princesa de Asturias w 2014 r., [Gehry, 2014]. Można nadmienić, że dziadkowie i matka Gehrego byli związania z Łodzią.

W sensie stylu budowli muzeum jest klasyfikowane, jako dekonstruktywizm, co wydaje się być nietrafne. Budowla ma wszystkie znamiona prawidłowej konstrukcji, poczynając od fundamentowania i kończąc na 
interesujących elewacjach. Bardziej właściwym określeniem jest collage, co jest ogólnie przypisywanym do Gehrego stylem architektonicznym, [Bennis, 2003].

Zgodnie z założeniem, atrakcyjności formy i ogólnie inność obiektu sprawiły dynamiczny, liczony w milionach, napływ turystów. Muzeum Guggenheima wraz z Museo de Bellas Artes de Bilbao przyciągają tłumy zwiedzających, [Gomez, Gonzalez, 2001], [Plaza, Haarich, 2013].
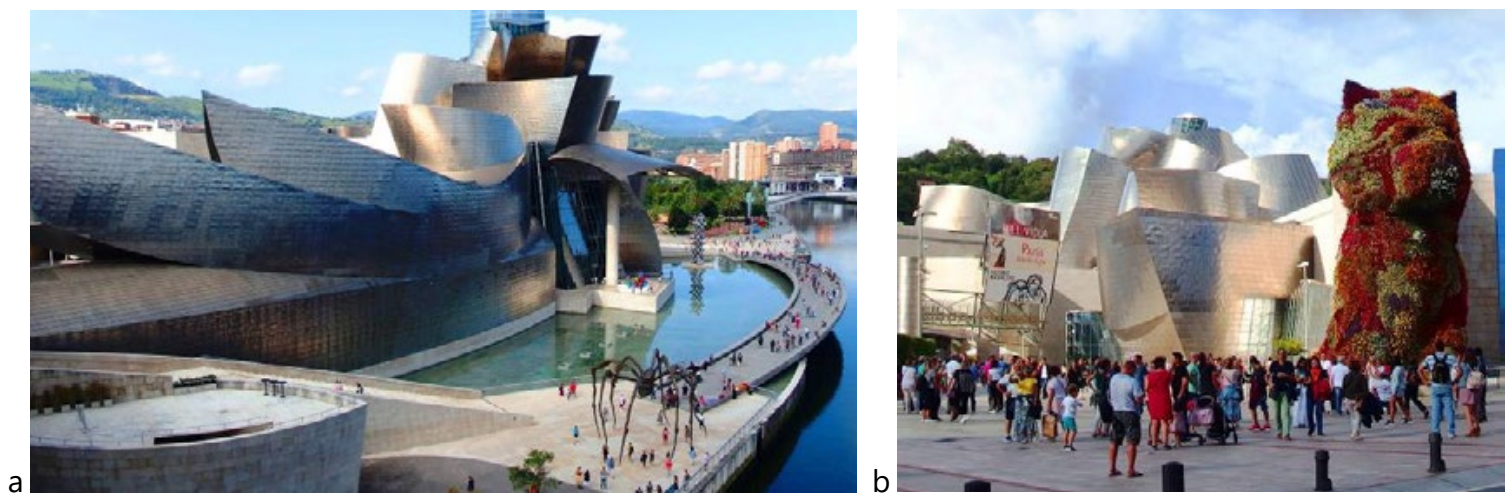

Ryc. 1. Guggenheim Museum Bilbao a) od strony zachodniej b) od strony południowej

Guggenheim Museum Bilbao a) from the west b) from the south

Budynek muzeum jest otoczony detalami architektonicznymi, które same w sobie są perełkami architektury/ rzeźby. Mamy tu: Maman (Pają) - pająka zaprojektowanego przez Louise Bourgeois - 1999 r., Tall Tree \& the Eye (Wysokie drzewo z kulek) zaprojektowane przez Anish Kapoor'a - 2009 r., Puppy (Szczeniak) - 1992 r. oraz Tulips (Tulipany) - 2004 r. wg projektów Jeff Koons'a. Omawiane rzeźby można dostrzec na zdjęciach na Ryc. 1.

Muzeum Guggeheima wraz z jego otoczeniem tworzą punkt węzłowy miasta, tak atrakcyjny architektonicznie, że przyciągają nie tylko turystów, ale także innych architektów, którzy chcą wpisać się w architekturę Bilbao swymi projektami.

Przedmiotem artykułu są mosty interesujące w sensie technicznym oraz architektonicznym. Mosty stare są kongruentne z dawną zabudową, podczas gdy nowe kreują lokalne dominanty architektoniczne.

\section{Mosty wzdłuż rzeki Nervion}

Niniejszy przegląd mostów nosi silne piętno subiektywnego postrzegania konstrukcji mostowych przez autora, jednakże w większości omawianych przypadków ma miejsce powielanie powszechnych ocen obrazów mostów. Mosty są prezentowane na zasadzie sekwencji kolejnych konstrukcji mostowych pojawiających się podczas umownego spaceru wzdłuż rzeki w kierunku jej ujścia do zatoki Biskajskiej.
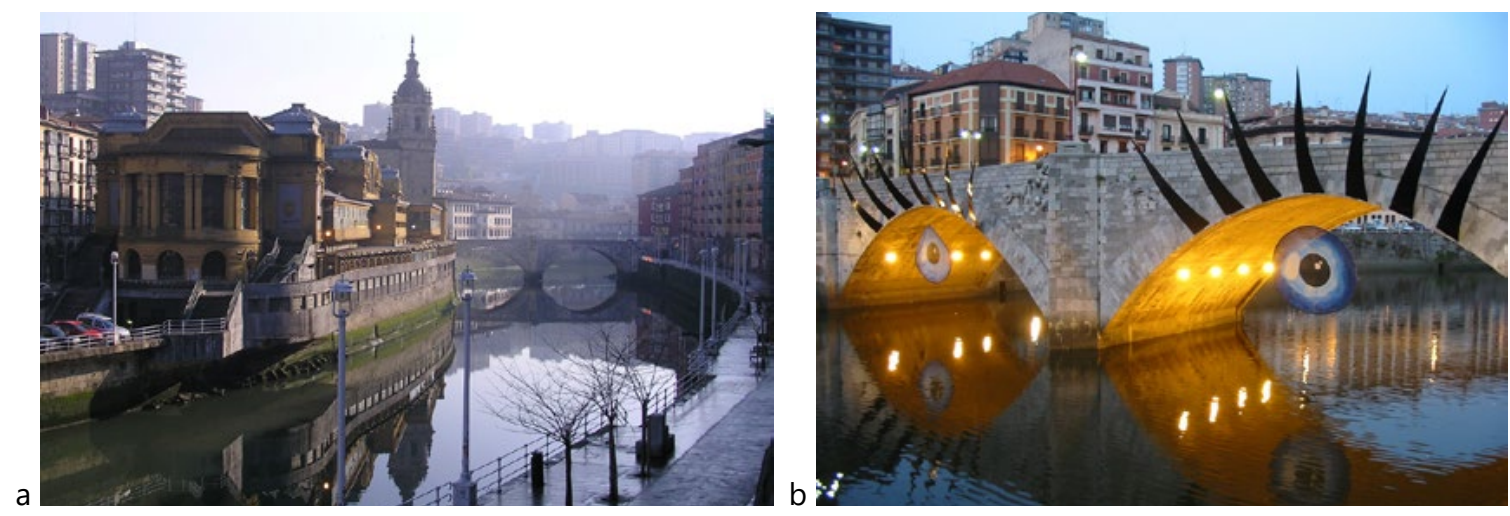

Ryc. 2. Łukowy most kamienny przy kościele św. Antona a) widok w górę rzeki b) dekoracja na czas fiesty Arch stone bridge at St. Anton church a) river upward view b) fiesta decoration 
W języku baskijskim most to zubia, wszystkie nazwy mostów są podane oryginalnie, czyli wjęzyku baskijskim, $\mathrm{np}$. San Antongo Zubia. Pierwszym z omawianych obiektów jest most przy kościele św. Antoniego. Został wybudowany w XX w. Jednakże w tym miejscu funkcjonowały kolejno most z XIV w., który przebudowano w roku 1602. Został zniszczony, a w jego miejsce powstał w 1877 roku drugi most zbudowany przez arch. inż. Ernesto Hoffmeyera [Bilbaopedia], który został zniszczony podczas hiszpańskiej wojny domowej w 1937 r. i w tym samym roku odbudowany.

Każdy most łukowy jest zawsze postrzegany łącznie ze swym lustrzanym odbiciem. Obserwator doznaje harmonii łagodnych podwójnych łuków, często kojarzonych z oczami mostu, [Bilbaopedia]. Bywa, ze obraz jest dodatkowo uszczegółowiony, Ryc. 2.b.

Rzeka na całym swym biegu przez miasto jest ujęta w kanał o ścianach z dawnych nabrzeży portowych. To sprawia, że dostęp do wody jest mocno ograniczony, jednocześnie obustronnie wzdłuż rzeki są szerokie pasaże dla pieszych i rowerzystów. Nocą pasaże są intensywnie i w pełni oświetlone, co w mieście jest podstawowym elementem bezpieczeństwa.

Około 600 m dalej w dół rzeki usytuowano żelbetową kładkę dla pieszych Erriberako Zubia (most przy nadbrzeżnym rynku), Ryc. 3. Jego poprzednikiem, w latach 1827 do 1852 był żelazny most wiszący. W roku 1881 zbudowano most żelazny belkowy, który został zniszczony w roku 1937. W tym samym miejscu, w roku 1939 otwarto nowy most żelbetowy, który w niezmienionej formie trwa do dzisiaj.
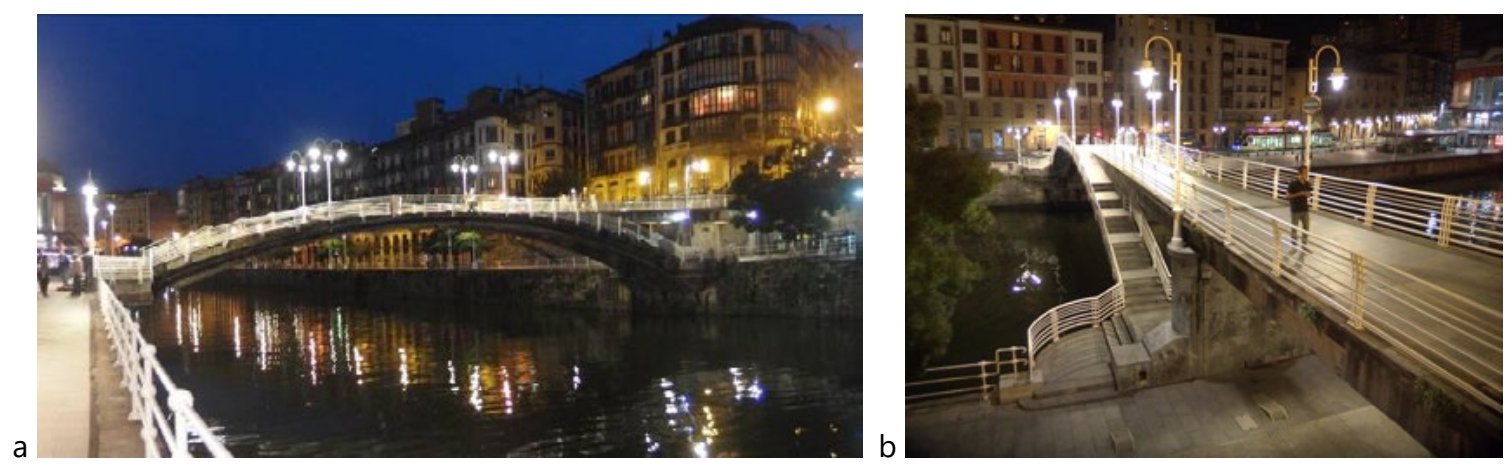

Ryc. 3. Kładka dla pieszych Erriberako Zubia a-b) oświetlenie w nocy

Footbridge Erriberako Zubia a-b) lighting at night

Można uznać, że most jest zaniedbany. Powierzchnie boczne betonu są pokryte zaciekami, są liczne spękania otuliny zbrojenia. W kategoriach oceny punktowej, stan techniczny to - dostateczny. Natomiast zastosowanie zwykłych prętowych balustrad o barwie białej tworzy urok tego mostu. To jest po prostu ładny synergiczny obraz tak w dzień jak i w nocy.
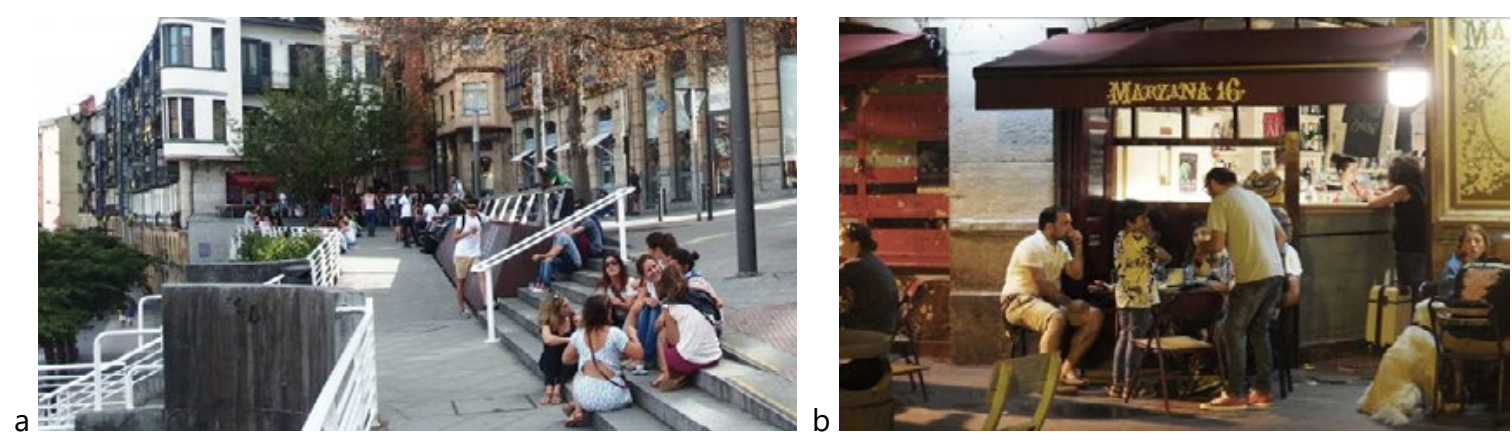

Ryc. 4. Tarasy Martzana

Martzana Terraces

Konstrukcyjnie wezgłowia łuku są na poziomie nabrzeży, przy czym ze względu na dostępność, po lewej stronie od klucza łuku biegnie pozioma belka do wyżej położonej ulicy Muelle Martzana, która wieczorami staje 
się miejscem węzłowym miasta. Ze względu na zmienności rzędnych ulica i chodniki dla pieszych tworzą pochylnie o niewielkich spadkach, tworzących tarasy. Wieczorami tarasy są wykorzystywane przez wielojęzyczny, wielokulturowy i barwny tłum bohemy, zwykłych mieszkańców i turystów, jako miejsce spotkań przy szklaneczce soku lub wina, Ryc. 4.a. Sprzyja temu sąsiedztwo płynącej rzeki, dobre oświetlenie i niskie ceny w niewielkim barze o nazwie Martzana.

W Bilbao białe balustrady są stosowane wszędzie wzdłuż rzeki. Na Ryc. 5. przedstawiono dwa kolejne mosty: Mesedeetako Zubia, Ryc. 5.a oraz Areatzako Zubia, Ryc. 5.b. Oba mosty są żelbetowe o przeciętnej urodzie, ale każdy z nich ma wielowiekowa historię.
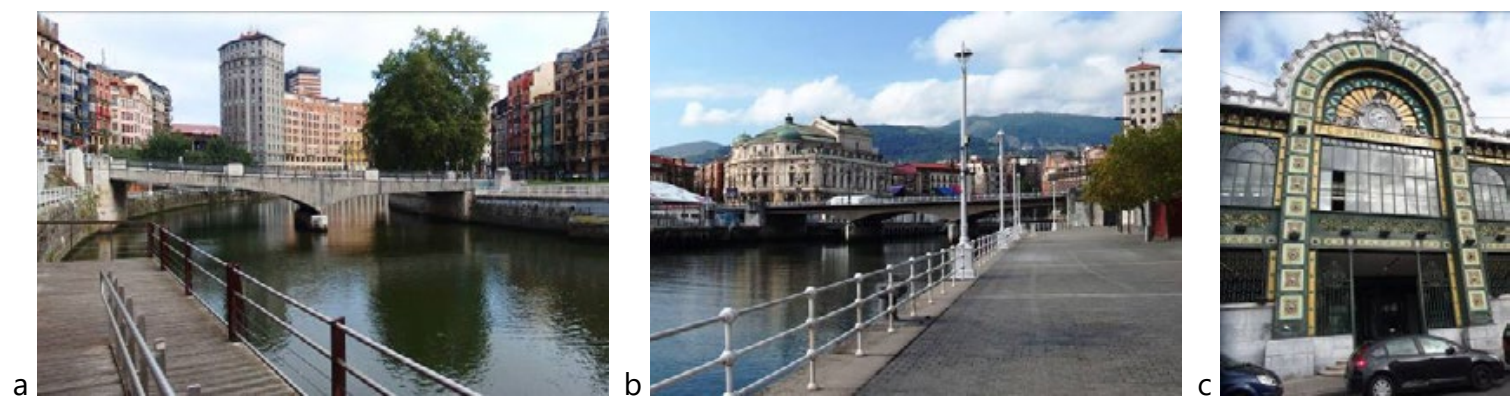

Ryc. 5. Żelbetowe mosty o ustroju ciągłym a) Mesedeetako Zubia b) Areatzako Zubia c) secesyjne wejście do stacji Santander RC continuous bridges a) Mesedeetako Zubia b) Areatzako Zubia c) the Art nouveau entrance to Santander station

Nazwa pierwszego z nich pochodzi od istniejącego w sąsiedztwie klasztoru Meseedeta. W tym miejscu pierwszy most drewniany zbudowali Franciszkanie w roku 1793. Został spalony w 1813 r. przez wycofującą się armię Napoleona. W 1886 r. most w obecnej formie zbudował E. Hoffmeyer. Został zniszczony w czasie hiszpańskiej wojny domowej i odbudowany przez inż. Manuel Gil de Santibañez w 1938 r.

Drugi z mostów, w obecnej formie został zbudowany w 1938 r. Oryginalnie, pierwszy most w tym miejscu powstał w roku 1848, jako drewniany o trzech łukowych przęsłach. Nosił imię królowej Elżbiety II. Most drewniany uległ zużyciu i w 1878 r. zbudowano kamienny most o trzech łukach. Most miał małe światło, dlatego mogły pod nim przepływać tylko małe łodzie. Po moście poprowadzono linie tramwajowa. Został wysadzony w powietrze w 1937 r. W roku 1940 firma francuska rozpoczęła budowę obecnego mostu. Przywrócono też nazwę mostu.

Oba mosty są położone w historycznym centrum Bilbao. Sąsiadują z dwoma stacjami kolei żelaznych, których tory biegną po obu stronach Nervion, przy czym budynek stacji do Santander (1902 r.) wyróżnia bogata elewacja w stylu modernizmu/secesji, zaprojektowanej przez architektów Valentín Gorbeña i Severino Achúcarro, Ryc. 5.c.

Na zdjęciu Ryc. 5.b widoczny jest gmach teatru im. Juana Arriaga, wzorowany na budynku opery paryskiej. Wybudowany w 1890 r. wg projektu arch. Joaquin de Rucoba.
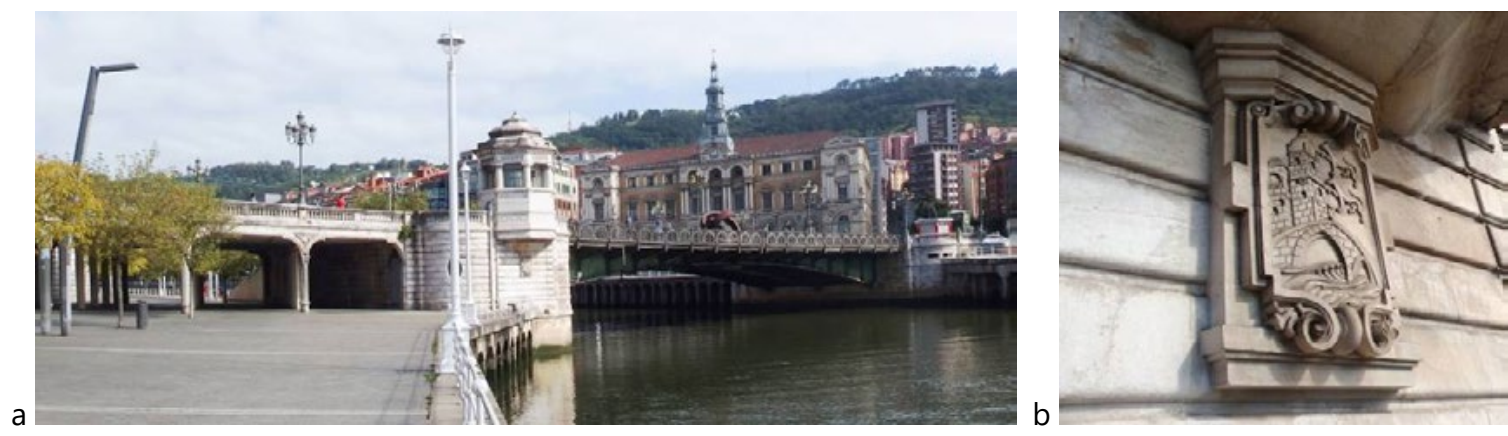

Ryc. 6. Udalexeko Zubia a) widok od napływu b) herb miasta Bilbao

Udalexeko Zubia a) view from the river influx b) arms of the city of Bilbao

Udalexeko Zubia, to następny most umiejscowiony przy ratuszu o długości 150 m, szerokośc 20 m. Ten obiekt jest oryginalny. Zaprojektowany przez inżynierów Ignacio Rotaetxe i José Ortiz de Artiñano na wzór mostów 
w Chicago. Oddany do ruchu w 1934 r, uszkodzony podczas wojny domowej został odbudowany. Most składa się z dwóch elementów: żelbetowej estakady na pasażem rzecznym oraz stalowego mostu właściwego nad ciekiem Nervion. Na stalowych łukach blachownicowych utwierdzonych obustronnie w podporach, ze stalowymi wspornikami chodników dla pieszych. Zastosowano ozdobna balustradę dla pieszych, Ryc. 6.

Można uznać, ze jest to rozwiązanie typowe, gdyż około $1 \mathrm{~km}$ dalej w dół rzeki istnieje analogiczna konstrukcji - Deustuko Zubia. W tym moście zamiast stalowych łuków blachownicowych zastosowano łuki kratownicowe ze skratowaniem w systemie Pratta.

Współczesne historia urbanistyki i architektury Bilbao umownie rozpoczyna się z chwilą otwarcia Guggenheim-Bilbao. Od tego czasu w Bilbao pojawiły się dzieła najsławniejszych architektów. Przykładem jest kładka dla pieszych Zubizuri Zubia (Biały most) zaprojektowana przez Santiago Calatravę,
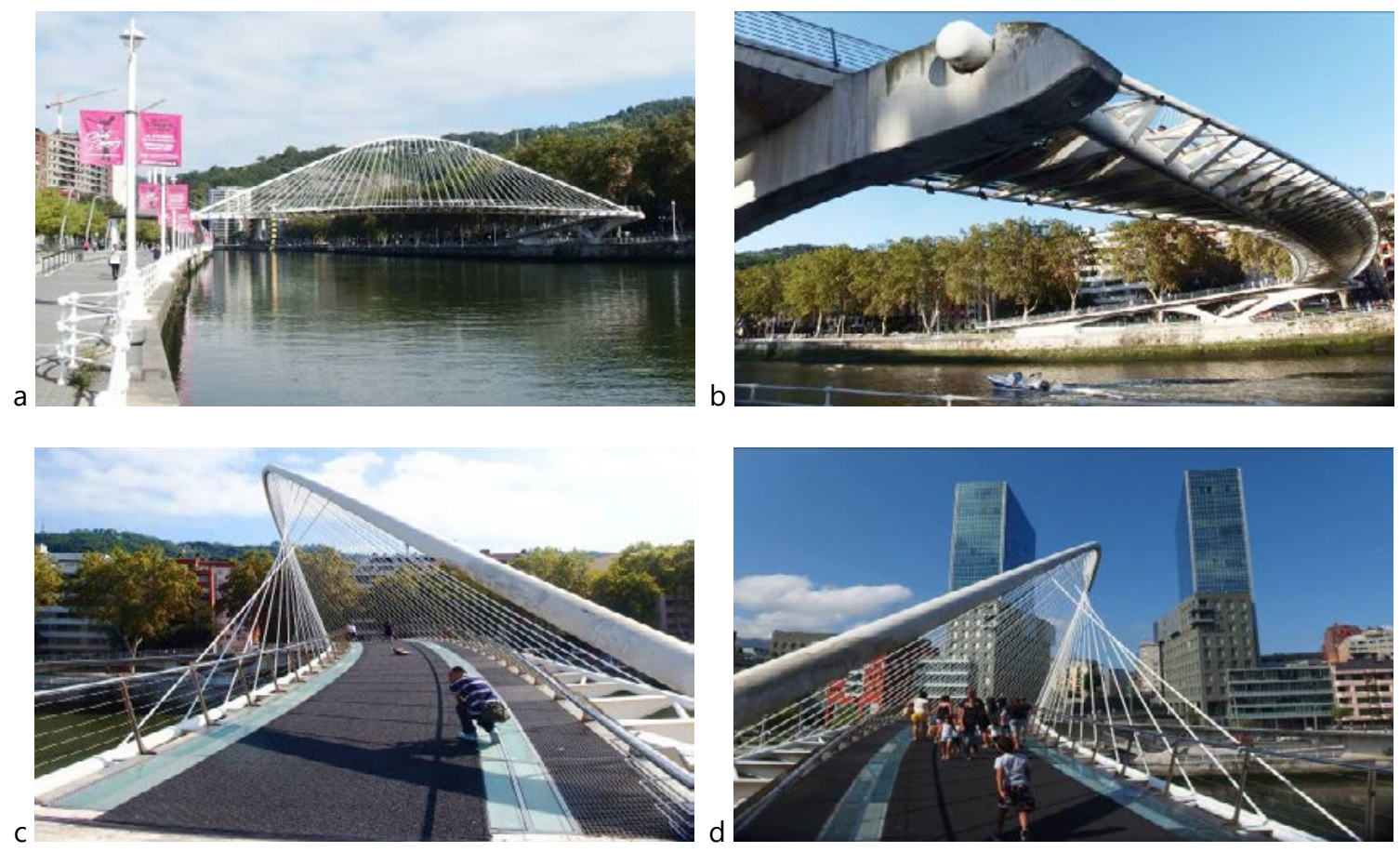

Ryc. 7. Zubizuri Zubia a) widok od napływu b) widok od spodu c) pomost d) kładka na tle Isozaki Atea Zubizuri Zubia a) inflow view b) bottom view c) platform d) footbridge and Isozaki Atea towers

Otwarcie nastąpiło w 1997 r. Niezłamana biel jest kolorem mostów Calatravy. W przypadku Zubizuri biel jest na tle wielobarwnej zabudowy miejskiej i naturalnej zieleni górzystej doliny Nervion. To jest mały most, jego długość i jednocześnie długość przęsła wynosi $75 \mathrm{~m}$. Szerokość pomostu około $7 \mathrm{~m}$. Jednakże ustrój nośny jest wysoki, jest relatywnie wysoko nad poziomem lustra wody $-8,5 \mathrm{~m}$. Wyniesienie łuku, dźwigara mostu, to 15,3 m. Klasyfikowanie tego mostu jako łukowy jest pewnym skrótem myślowym. Właściwie, to nie jest łuk, to jest trójkąt ze ściętym wierzchołkiem linią paraboli. Ustrój nośny wykonano ze stali, pomost ze szkła hartowanego klejonego warstwami. W układzie przestrzennym łuk jest odchylony od pionu o 10 deg. Pomost jest w niewielkim łuku poziomym. Wezgłowia łuku są spięte ściągiem rurowym, który ma niewielkie, ale wyraźnie dostrzegalne, wyniesienie ku górze. Balustrady słupkowe z pochwytem ze stali nierdzewnej, przeciągi z linek stalowych nierdzewnych. Wieszaki w rozstawie około 1,8 m, po 39 sztuk po każdej stronie. Układ wieszaków w widoku z boku, w przybliżeniu odpowiada systemowi radialnemu, jednakże w swej istocie nim nie jest. Wieszaki są tworzącymi powierzchni prostokreślnych, dokładnie jak w zadaniach z geometrii wykreślnej. Most jest nowoczesną konstrukcją, choćby z tego powodu, że nie daje się ująć w typowe schematy czy systemy, [Zychowska, 2015].

Dynamicznie kładka jest sztywna. Próby wzbudzenia przęsła przez skoki w miejscu o odciętej L/4 nie wywołały spodziewanych drgań. 
Na zdjęciu Ryc. 7.d, w tle widać osiemdziesięciometrowe wieżowce japońskiego architekta Arata Isozaki'ego, którego do Bilbao przyciągnęła chęć udziału w architekturze tego miasta.
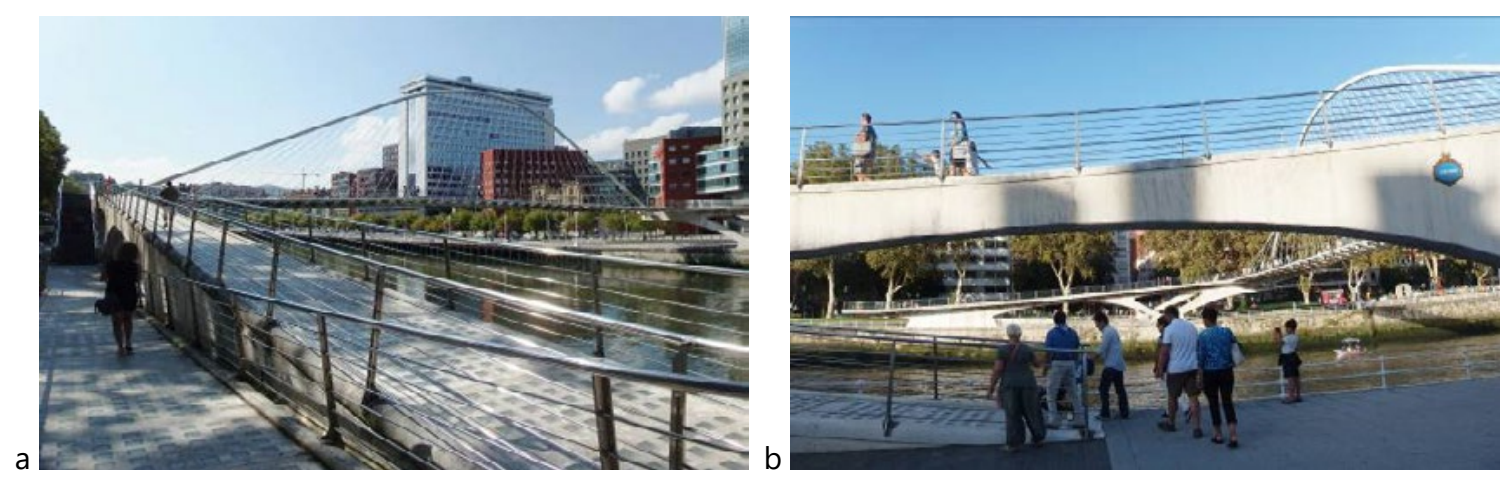

Ryc. 8. Dojścia do kładki Zubizuri Zubia a) schody i ażurowe pochylnie do kładki b) łuki i wspornik pochylni

Access to the Zubizuri Zubia a) stairs and openwork ramps to the footbridge b) arches and ramps

Kolejną osobliwością konstrukcji jest zastosowanie dojść do pomostu za pomocą pochylni i schodów usytuowanych prostopadle do umownej osi pomostu, Ryc. 8. Dojścia wykonano z żelbetu, którego eksponowane powierzchnie pokryto farbą białą. Tworzy to zamierzony chaos, który przechodniowi daje chwilę na refleksję połączoną z kulminacją zbliżania się do przejścia nad wodą. Pomosty pochylni są betonowe ze licznymi regularnymi świetlikami szklanymi, które zastępują latarnie. Pochylnie są ułożone na obróconych łukach parabolicznych, co konweniuje z nietypowością dźwigara łukowego kładki. Dbałość o każdy szczegół architektoniczny dotyczy też, usytuowania typowej tablicy z nazwą mostu.
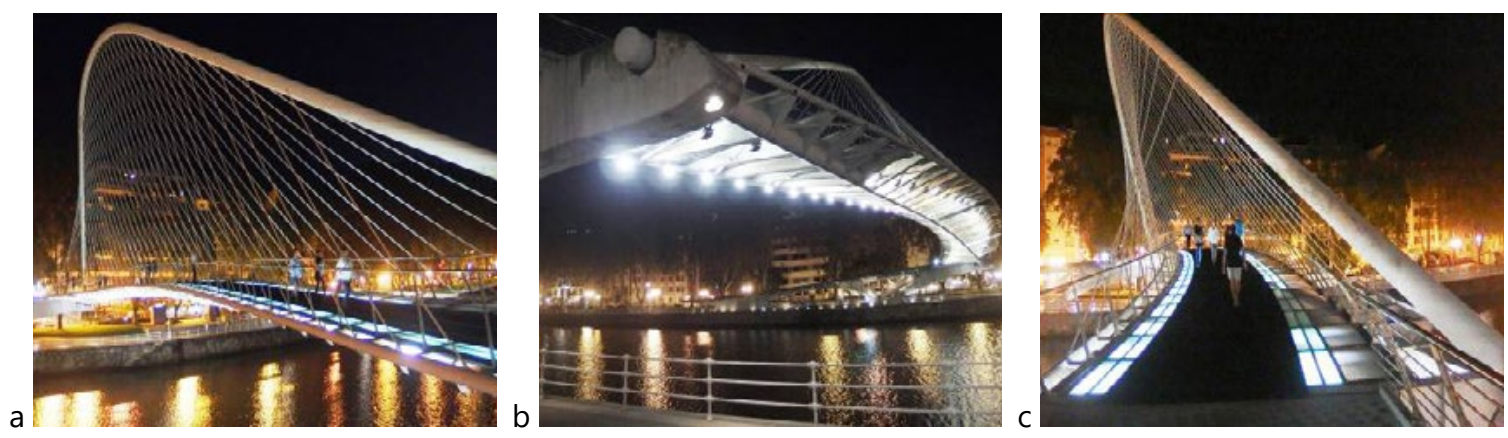

Ryc. 9. Zubizuri nocą a) widok z boku b) widok od spodu c) widok wzdłuż pomostu The Zubizuri at night a) side view b) bottom view c) view along the path walk

Bywa tak, ze nawet najwspanialsze dzieła architektoniczne nie zawsze spełniają kryteria użytkowalności. Tak jest w przypadku weneckiego mostu Calatravy Ponte della Costituzione. Schody i pomost tej kładki dla pieszych wykonano ze szkła hartowanego, którego powierzchnia podczas opadów deszczu stają się śliskie do tego stopnia, że miały miejsce liczne kontuzje pieszych. Podobnie było w Bilbao, jednakże tu, na drodze kompromisu, główna część pomostu została wyłożona szorstką wykładziną. W efekcie, przy niewielkim ograniczeniu skrajni ruchu pieszego, jednocześnie zapewniono dostateczną szorstkość chodnika i dostateczne oświetlenie za pomocą obrzeży prześwietlanego światłem od spodu szkła. lluminacja nocna kładki jest wystarczająca by ją wyraźnie dostrzegać ze szczegółami, przy czym należy pamiętać, że zawsze jest problematyczne i niedoskonałe podświetlenie wieszaków, istotnych w mostach wiszących i podwieszonych, Ryc. 9.

Most Calatravy w Bilbao, podobnie jak kładka Katehaki w Atenach [Karas, 2016], wywołuje wrażenie niedosytu. Jej przestrzenność, transparentność i bogactwo geometryczne sprawiają, że nie daje się jej dobrze sfotografować. Wykonywanie dużej liczby zdjęć tylko powiększa stan niedosytu i niespełnienia, gdyż nawet wtedy ma miejsce oczekiwanie czegoś więcej. Tak więc, mimo iż konstrukcja jest niewielka, nie ma tu pełnego obrazu mostu. Niewykluczone, że jest to rezultat założenia On the Foldability of Frames [Calatrava, 1981]. 
Salbeko Zubia (hisp. Puente de la Salve) jest integralnym elementem kompleksu architektonicznego muzeum Guggenheima, Ryc. 10.
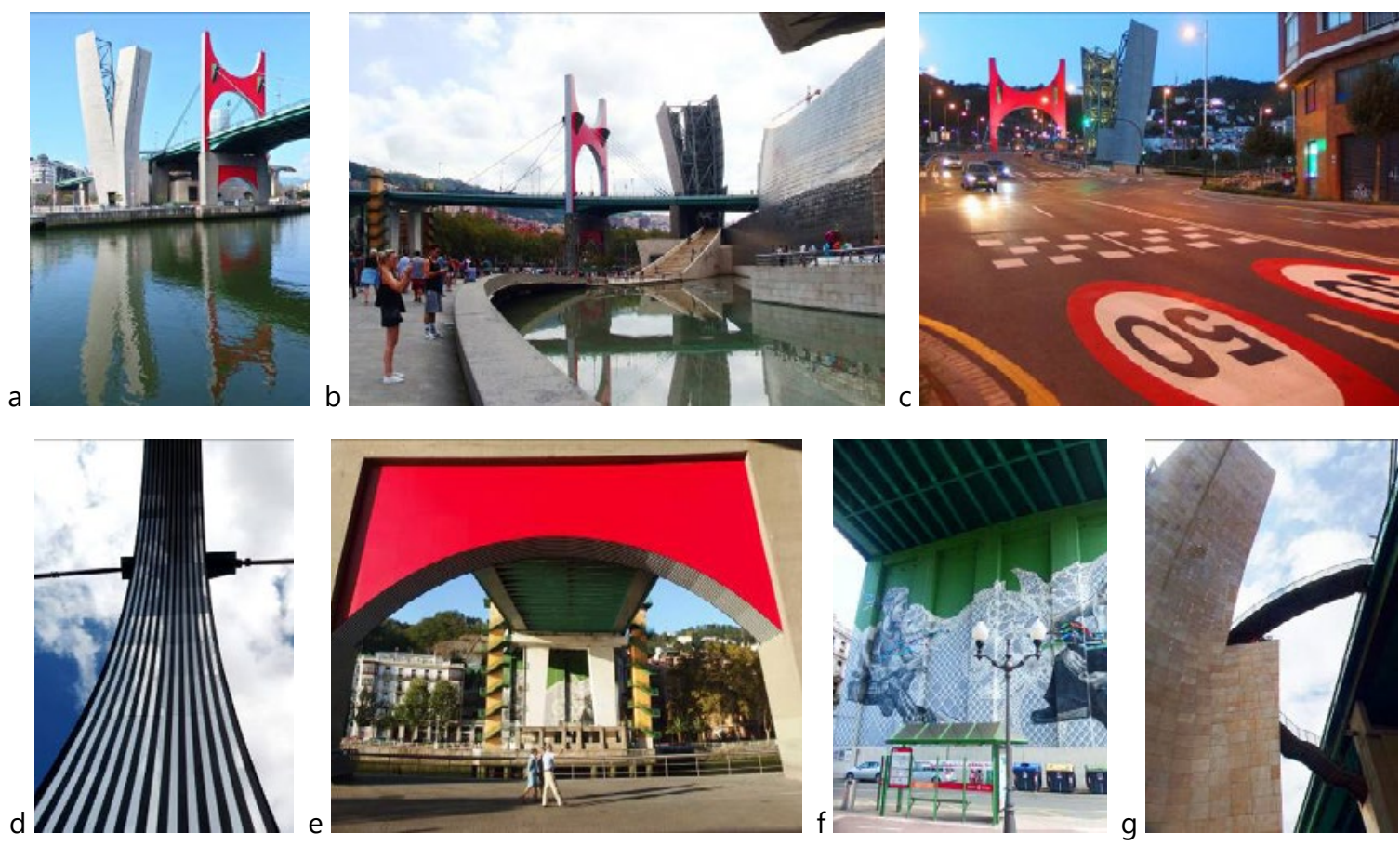

Ryc. 10. Salbeko Zubia a) widok od strony Zubizuri b) widok od muzeum c) pylon/portal od lewobrzeżnej części miasta d) listwy iluminacyjne e) widok z poziomu promenady f) mural g) ganek

Salbeko Zubia a) view from the Zubizuri side b) view from the museum c) pylon/portal from the left-bank d) illuminations e) view from the promenade level f) mural g) porch

Nazwa mostu pochodzi od pozdrowienia żeglarzy na cześć Najświętszej Marii Panny, która miała się objawić w miejscu bazyliki de Nuestra Señora de Begoña na początku XVI wieku. Była to pierwsza konstrukcja podwieszona w Hiszpani. Ortotropowy pomost i pylon są stalowe, podczas gdy filary i przyczółki są z betonu o barwie lekko zielonej. Wyniesienie pomostu ponad lustro rzeki wynosi 23,5 m. Most zaprojektował Juan Batanero, otwarcie nastąpiło w 1972. Należy podkreślić, że F. Gehry uwzględnił bezpośrednie sąsiedztwo mostu w swym projekcie budynku muzeum, tak by obie budowle wzajemnie się eksponowały. Z mostu poprowadzono przejścia na dodatkowy punkt widokowy tzw. Arkupe (Ganek), Ryc. 10.g. Na prawym pylonie nabrzeżnym zainstalowano bezpłatne windy do pomostu, umożliwiające widok na całej długości mostu na muzeum z poziomu jego dachów. Most jest elementem arterii miejskiej. Obecna forma mostu powstała w 2006 r. i jest dziełem francuskiego artysty Daniela Burena [FMGB Guggenheim Bilbao, 2017]. Pylon nosi nazwę Arku gorriak (Czerwony Łuk). Artysta, na zasadzie kolorystycznego kontrastu do zieleni zastosował silną czerwień pokrywającą powierzchnie czołowe pylona. Powierzchnie boczne wykonano z 655 listew wyposażonych w 11 diod o mocy 2W, które za dnia są widoczne jako srebrne metaliczne listwy, a nocą iluminują konstrukcję. Masywny, zielony filar przy pasażu miejskim jest ozdobiony szarym muralem o powierzchni około $1000 \mathrm{~m}^{2}$, nosi nazwę Puente del Príncipe y la Princesa de España. Mural nosi w sobie głębokie przesłanie sztuki i niwersalizmu, jednakże w zwykłum ujęciu jest znakomitą implementacją rozbicia monumentalnej zielonej ściany przez wyraźne stonowanie szarym delikatnym rysunkiem.

W dół rzeki, za muzeum wybudowano kładkę dla pieszych noszące imię baskijskiego polityka Pedro Arrupe Zubia. W subiektywnym odczuciu autora, kładka jest konstrukcją architektonicznie obcą. Natomiast ma silny, choć negatywny/smutny obraz kubistyczny, Ryc. 11.

Autostrady miejskie omijają centrum. Ze swej natury komunikacyjnej ich mosty nad Nervionem są duże, co do gabarytu, mimo to można dostrzec wiele interesujących elementów architektury mostów w całości i w detalach ich wyposażenia. Na Ryc. 12 zamieszczono kilka przykładów. 

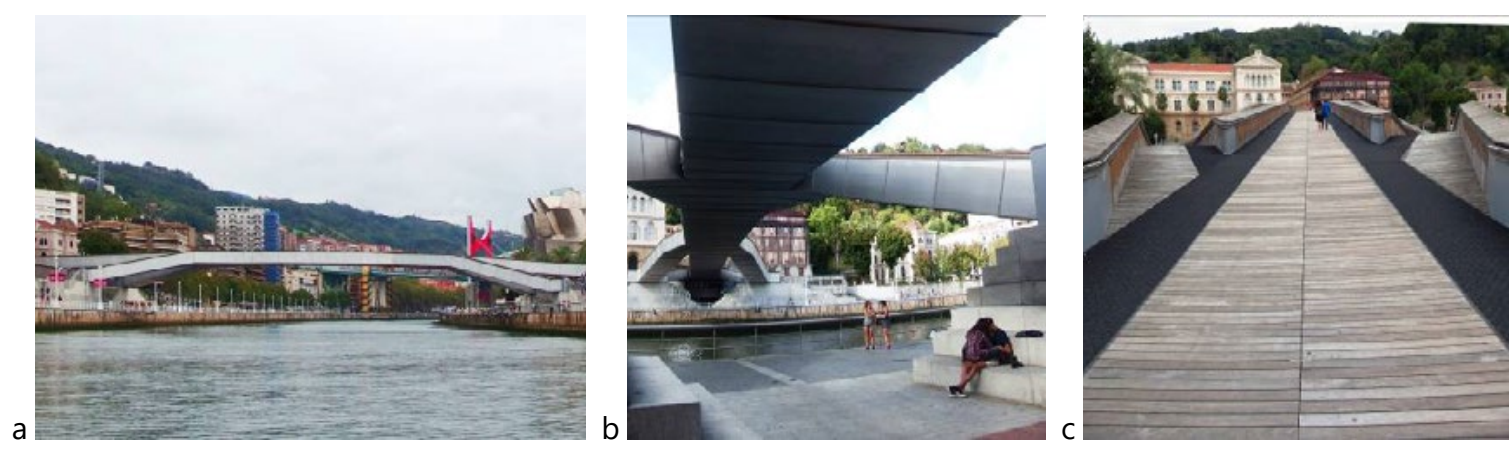

Ryc. 11. Pasarela Pedro Arrupe a) widok od dolnej wody b) widok z dołu c) drewniany pomost

Pasarela Pedro Arrupe a) view from the lower water b) bottom view c) wooden footpath

a
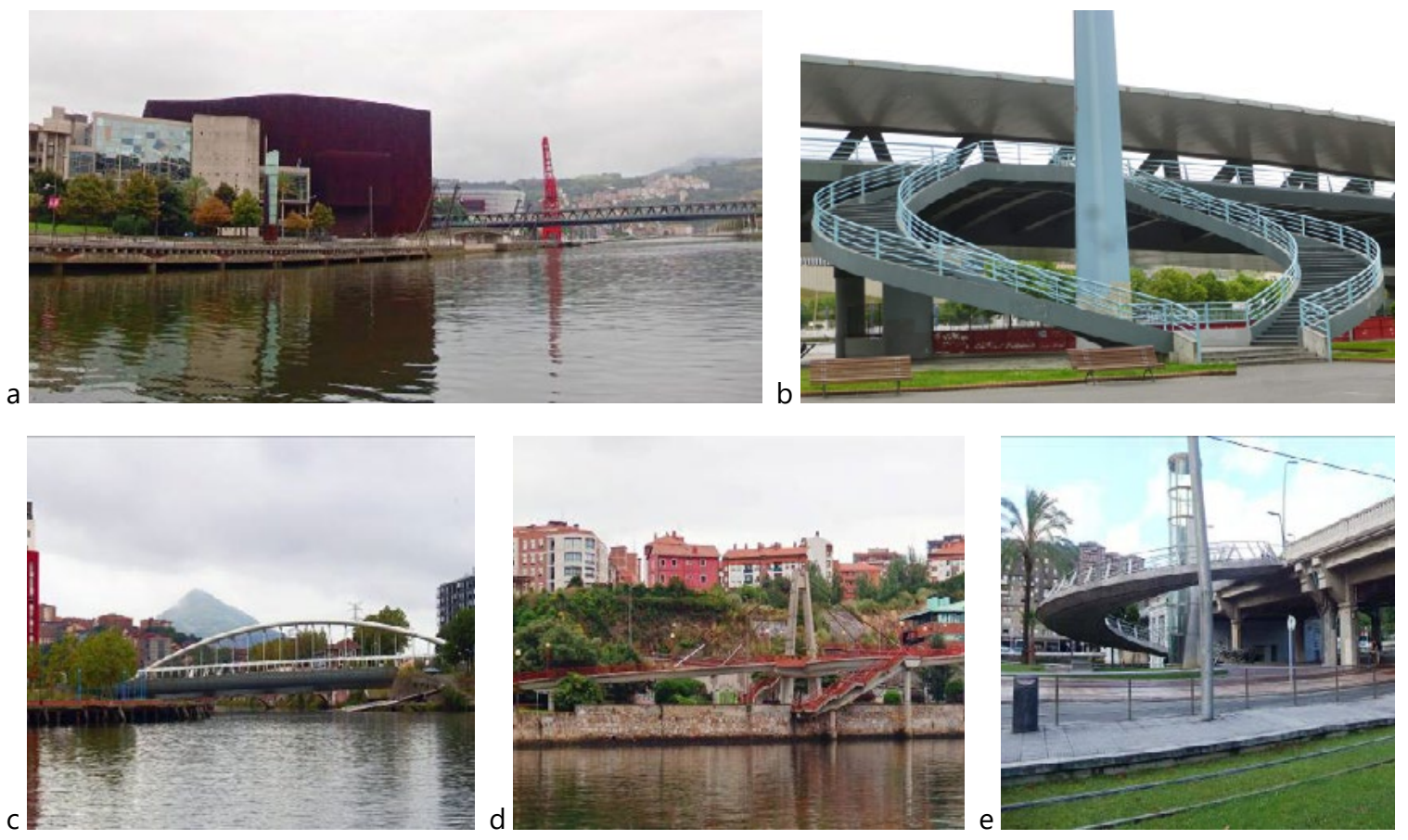

Ryc. 12. a-b) Euskalduna Zubia c) hybrydowy most stalowy o jednym łuku, Altos Hornos d) żelbetowy most podwieszony nad ul. Madaripe Bidea e) Deustuko Zubia, wejście na most

a-b) Euskalduna Zubia c) hybrid steel bridge with one arch, Altos Hornos d) RC suspension bridge over Madaripe Bidea str. e) Deustuko Zubia, entering the bridge

Na wszystkich zdjęciach, w tle mostów jest widoczna zabudowa kwartałowa. Tak budynki z okresu prosperity przemysłowej jak i współczesne są ciekawymi obiektami z licznymi balkonami i lodżiami, o interesującej kolorystyce ich elewacji. Z tego powodu, na Ryc. 13 zamieszczono kilka ujęć budynków Bilbao.

Ostatnim mostem na rzece Nervion jest Bizkaiko Zubia, Ryc. 14, usytuowany między satelitami Bilbao w ujściu rzeki, Portugalete i Getxo. Powszechnie nazywany jest Puente Colgante (most wiszacy). Most jest zabytkowy, w 2006 został uznany jak obiekt światowego dziedzictwa UNESCO w kategorii technicznej, [UN World Heritage List, 2006]. Funkcjonuje bez przerwy od swego powstania, z krótką przerwą w roku 1937. 

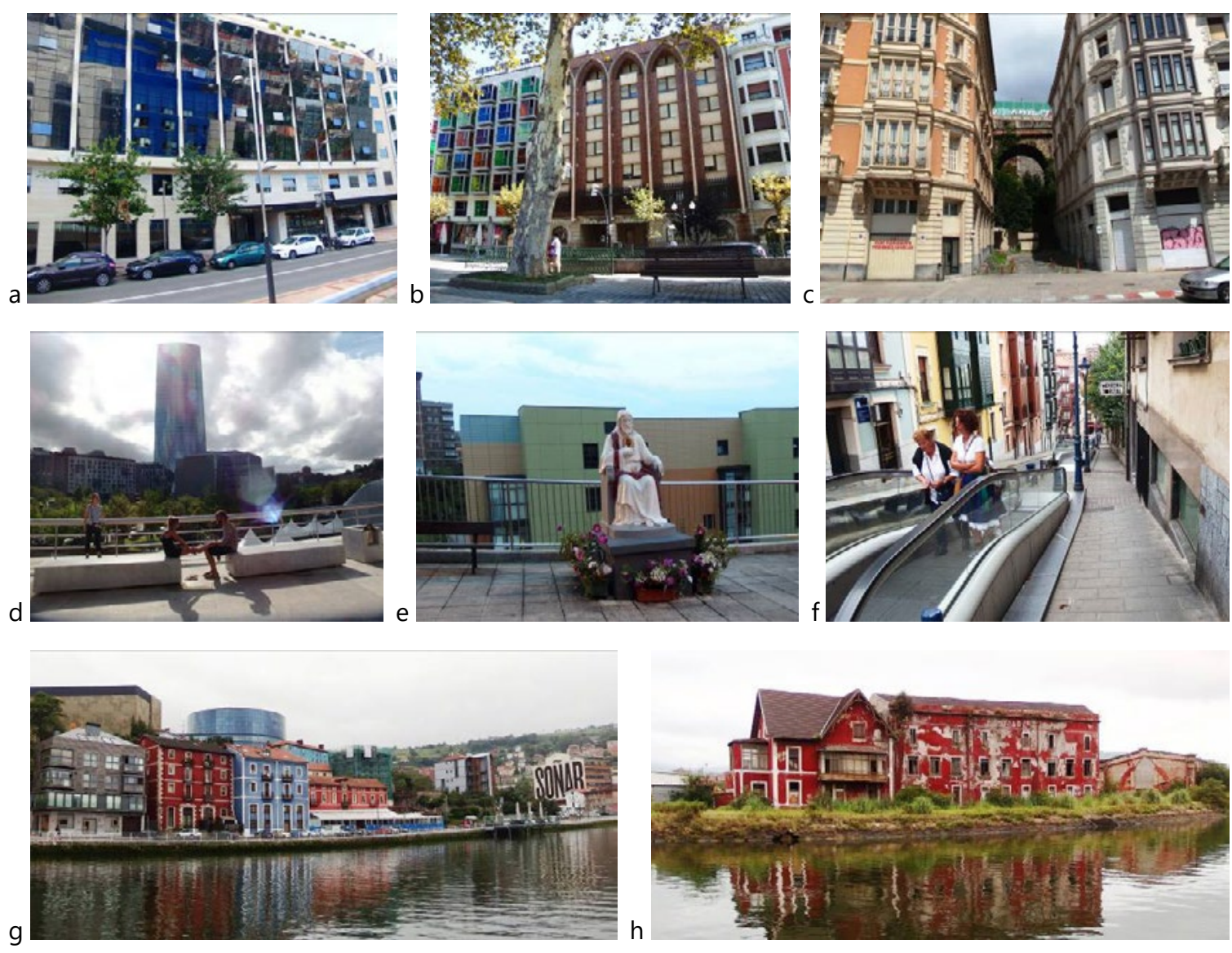

Ryc. 13. Zabudowa kwartalna a) szklana elewacja budynku przy muzeum b-c) historyczne centrum miasta d) Torre Iberdrola, César Pelli, 2007 r. f) ruchome pochylnie w Portugalete g-h) opuszczone budynki w ruinie w dolnym biegu Nervionu

Quarter buildings a) building glass elevation at the museum b-c) historical city center d) Torre Iberdrola, César Pelli, 2007 f) escalators in Portugalete $\mathrm{g}$ - $\mathrm{h}$ ) abandoned buildings in the ruins at Nervion River end

Architektonicznie został zaprojektowany przez Alberto Palacio, który wywodził się z grupy architektów związanych z Gustavem Eiffel, natomiast konstruktorem był inż. Ferdinand Arnodin. Uruchomienie mostu nastąpiło w roku 1893. Materiałem konstrukcyjnym wież i kratownicowego pomostu jest żelazo, podczas gdy element nośny - liny - są stalowe. Całkowita długość mostu wynosi $164 \mathrm{~m}$, wysokość wież to $61 \mathrm{~m}$, a pomost dla zwiedzających jest na poziomie $50 \mathrm{~m}$. Gondola funkcjonuje w odstępie $1 \mathrm{~min}$.

W przypadku większości ważnych obiektów architektonicznych lub przemysłowych w ich sąsiedztwie są plansze informacyjne z danymi chronologicznymi i opisem miejsca, Ryc. 15.

Sukces medialny związany z mostem jako obiektem technicznego dziedzictwa światowego sprawił, że pojawiło się w świecie zapotrzebowanie na mosty gondolowe. Mosty tego typu nie są efektywnym elementem transportu, natomiast podobnie jak Bizkaiko Zubia są magnesem turystycznym, interesującym z charakterystyczną dominantą w krajobrazie, Ryc. 14. a-b. Zadziwiające jest to, że po 100 latach funkcjonowania most w dalszym ciągu jest, w sensie technicznym, nowoczesny.

Mosty są elementem systemu transportowego, dlatego jeszcze kilka słów o metrze w Bilbao. Są dwie linie metra po obu stronach rzeki Nervion, oddane do użytkowania w 1995 r. W większości jest to metro podziemne, a tylko na kilku odcinkach biegnie po powierzchni. Perony i wejścia do metra zaprojektował architekt Norman Foster. Prostota, przejrzystości sytuacji komunikacyjnych, funkcjonalność i charakterystyczne baldachimowe wejścia do metro stały się sukcesem ich projektanta, Ryc. 16. a-b. 

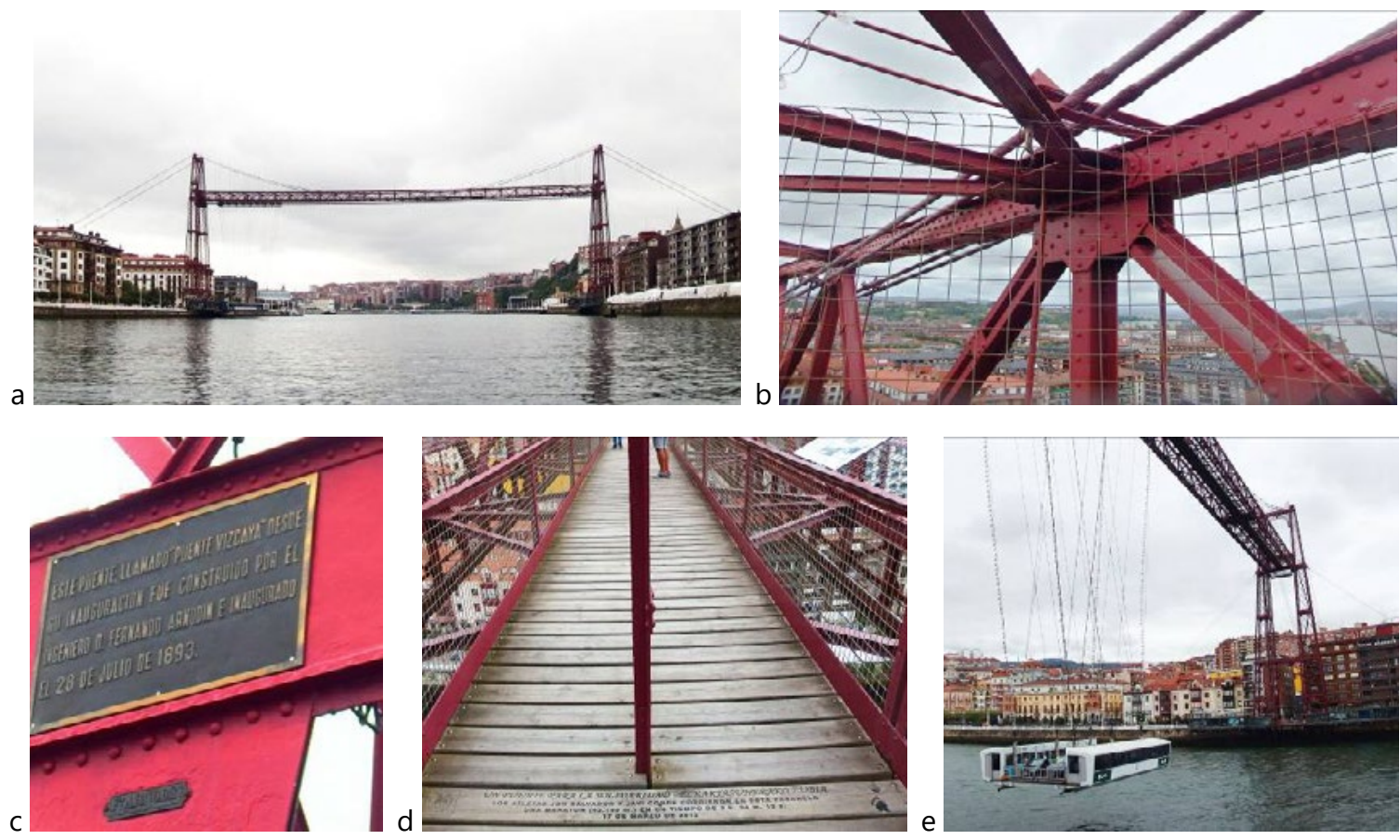

Ryc. 14. Bizkaiko Zubia a) widok od strony Zatoki Biskajskiej b) szczegół węzła kratowego i mocowania stalowych lin c) tablica znamionowa mostu d) drewniany pomost dla turystów d) gondola samochodowo-pasażerska

Bizkaiko Zubia a) view from the Bay of Biscay b) detail of the lattice and fixing of steel ropes c) bridge's table d) wooden footpath for tourists d) car/passenger gondola
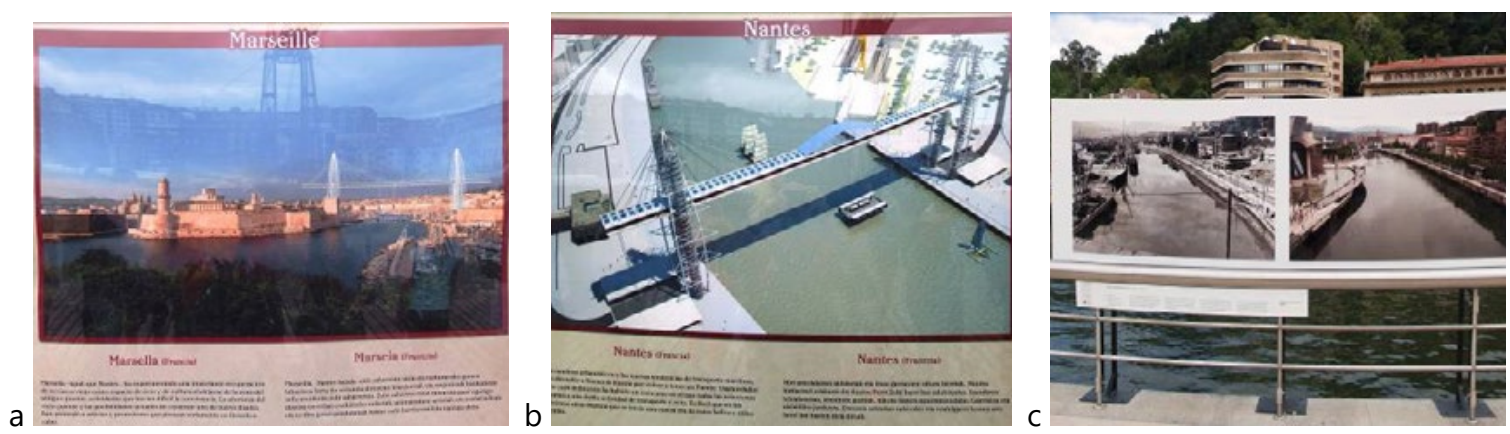

Ryc. 15. Plansze informacyjne a-b) projekty mostów gondolowych w Marsylii i Nantes d) krajobraz dawnie i obecnie okolic muzeum Guggenheima

Information boards a-b) projects of gondola bridges in Marseille and Nantes d) landscape of the past and present surroundings of the Guggenheim museum 

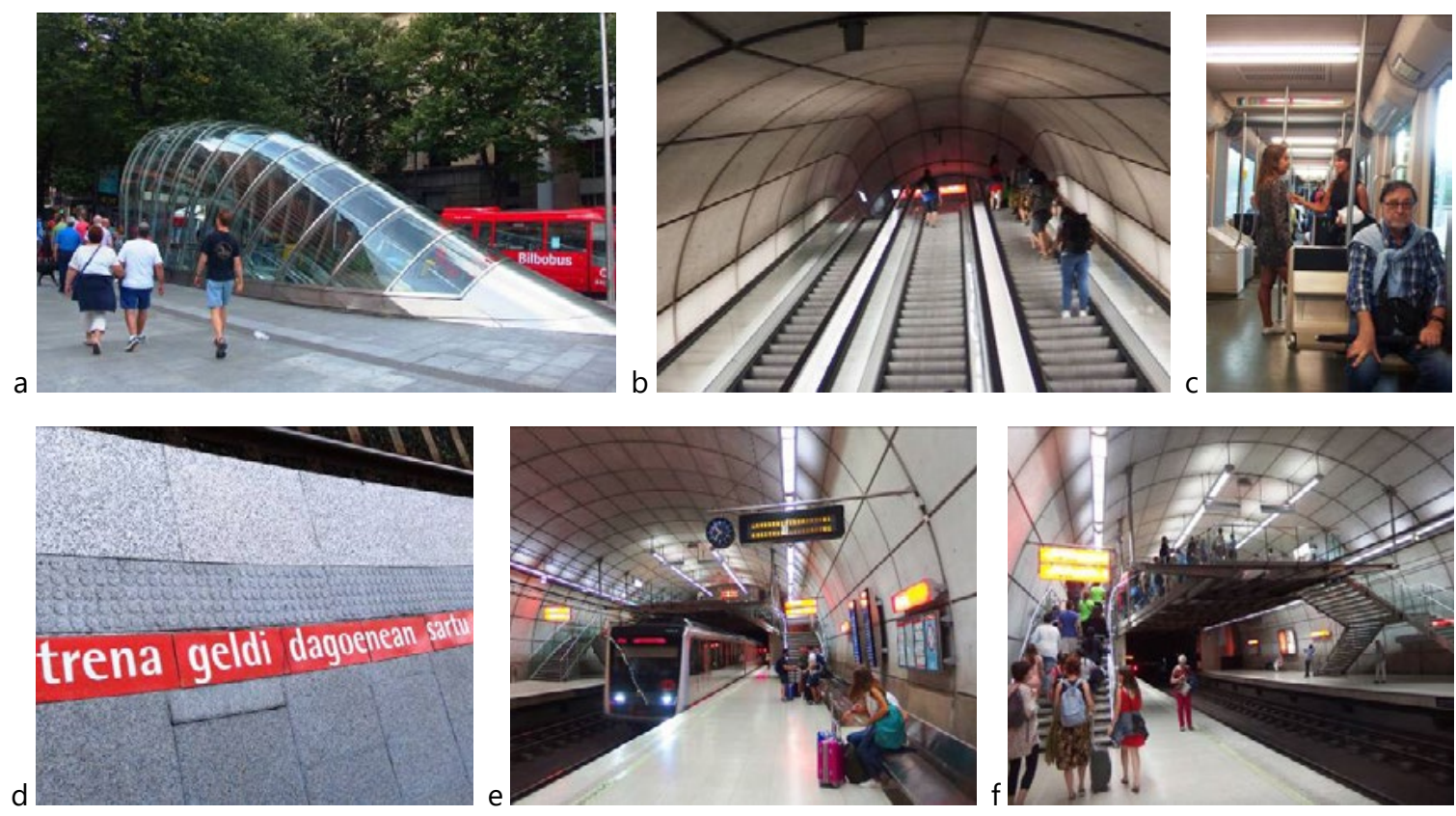

Ryc. 16. Metro w Bilbao a) charakterystyczne baldachimowe wejście b) surowa schludność dojść do peronów c) wnętrze wagonów d) oznaczenia komunikacyjne e-f) perony

Bilbao Metro a) characteristic canopy entrance b) strict neatness of platforms'approaches c) interior of wagons d) communication markings e-f) platforms

\section{Most w Vitoria-Gasteiz i San Sebastian}

Bez wątpienia najbardziej interesujące w zakresie historycznym i architektonicznym są mosty Bilbao. Jednakże warto jest także zwrócić uwagę na mosty w stolicy kraju Vitoria-Gasteiz i jednej ze stolic festiwalowych filmu światowego - San Sebastian.

Centrum miasta Vitoria nie jest związane z żadną rzeką, dlatego nie ma tu interesujących mostów. Jednakże, na jego obrzeżu, w sąsiedztwie dworca autobusowego odnajdujemy rzeźbę mostową, która w swej istocie jest nieładnym, a nawet turpistycznym zaburzeniem otoczenia i przez to interesująca próbą kształtowania lokalnej dominanty, Ryc. 17.
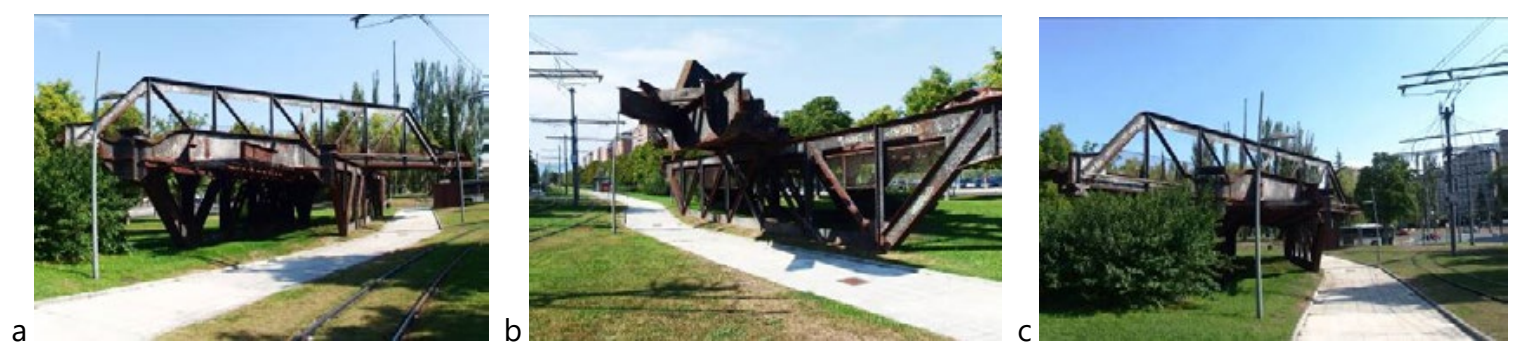

Ryc. 17. Vitoria-Gasteiz, rzeźba mostowa a-c) różne ujęcia

Vitoria-Gasteiz, bridge sculpture a-c) different shots

Zamiast złomować stare kratownice i pomost mostu kolejowego zdecydowano o częściowej rozbiórce i ponownym ustawieniu powstałych elementów. Ich układ w żaden sposób nie jest konstrukcyjny, decydowała forma przestrzenna. Celowo stalowe elementy o długości około $30 \mathrm{~m}$ pozostawiono w ich pierwotnej formie. Resztki powłok ochronnych nie chronią od rozwoju korozji, która objęła większość węzłów i powierzchni prętów. 
Obraz rzeźby z elementów mostu jest odstraszający, nie zachęca do krótkiego przystanku, mimo bezpośredniego sąsiedztwa chodnika dla pieszych. Turpizm jest spotęgowany regularnym otoczeniem zieleni miejskiej.

Mosty w San Sebastian nad rzeką Urumea można określić, jako wytworne i nie jest to zabieg erudycyjny, Ryc. 18.
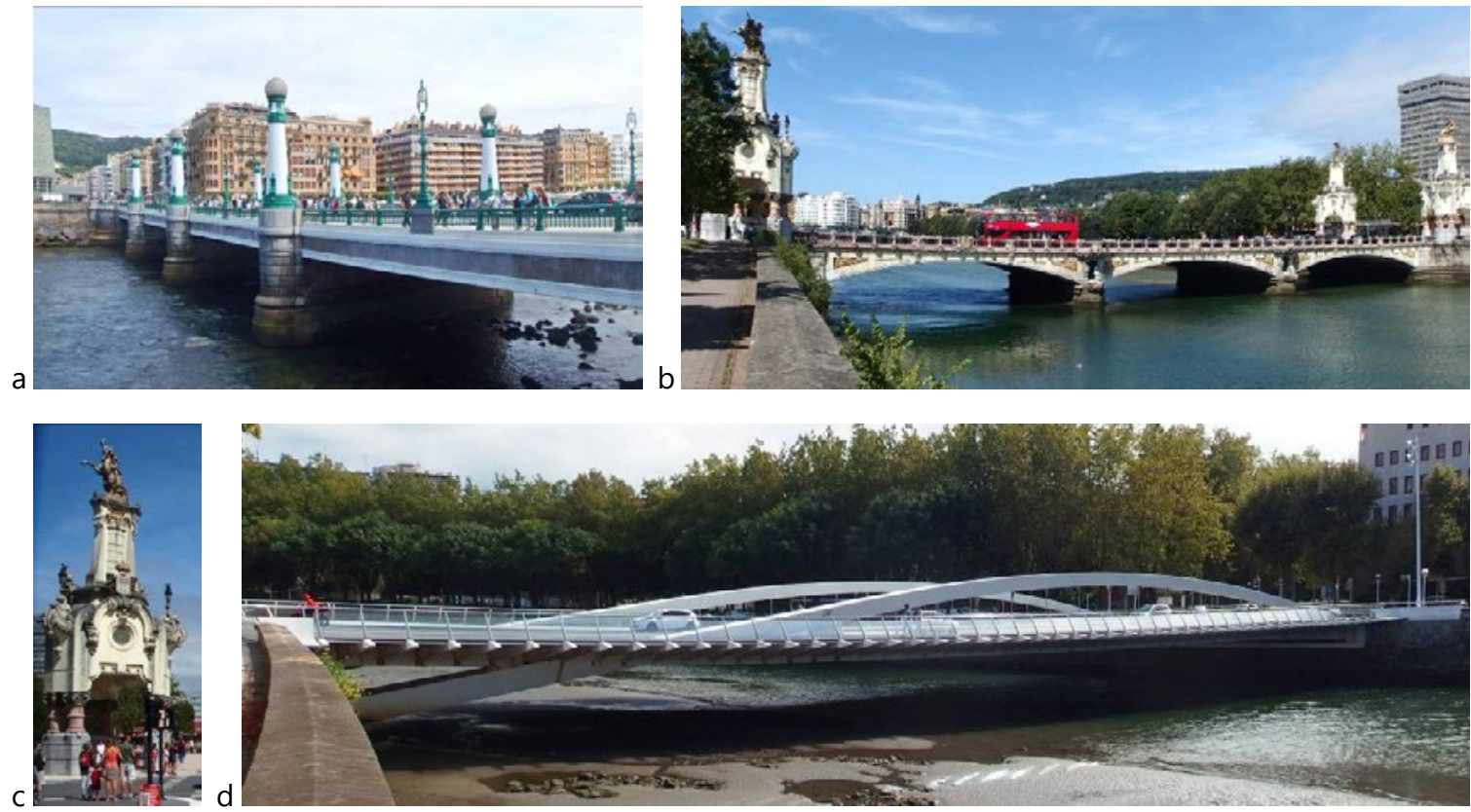

Ryc. 18. Mosty w San Sebastian a) Kursaal Zubia b) Maria Cristina Zubia c) narożny fial d) Agirre Zubia

Bridges in San Sebastian a) Kursaal Zubia b) Maria Cristina Zubia c) corner pinnacle d) Agirre Zubia

Kursaal Zubia wybudowano w 1921 r. Jest położony u ujścia rzeki Urumea, tuż obok Kursaal Congres Center (Kursaal Cubes). Cecha wyróżniającą most spośród innych są lampy oświetleniowe zaprojektowane przez Víctor Arana w stylu Art Deco.

Poprzednikiem obecnego Maria Cristina Zubia był most drewniany wybudowany w 1893 r. Obecnie funkcjonujący obiekt wybudowano w roku 1905, Ryc. 18.b. Konstruktorem był Eugenio Ribera a architektem Julio Zapata. Atrybutem tego mostu są fiale/wieże narożne na końcach pomostu o wysokości około $10 \mathrm{~m}$, Ryc. 18.c. Obeliski są w stylu naśladującym habsburskie budowle charakterystyczne dla Wiednia i Madrytu.

Elegancki most Agirre Zubia wybudowano w 2011. Zdaniem autora, jest to bardzo udane naśladownictwo mostów Calatravy. Długość łuku wynosi $80 \mathrm{~m}$, szerokość mostu to $29 \mathrm{~m}$. Dwa równoległe łuki ze stali nierdzewnej Dúplex mają wezgłowia na różnych poziomach czy czyni go geometrycznie asymetrycznym. Łuk jest o małej wyniosłości równej 1/8 jego rozpiętości, Ryc. 18.d.

\section{Podsumowanie}

Załamanie prosperity przemysłowej w Bilbao skutkowało upadkiem miasta we wszystkich aspektach. Nowoczesna architektura stała się remedium na odrodzenie przez sztukę. Miasto stało się atrakcyjne nie tylko turystycznie, ale także dla architektów, którzy chcą dołączyć do sukcesu, którego mianem jest w dalszym ciągu budynek i muzeum Guggenheim Bilbao.

Mosty Bilbao nad rzeką Nervion są nieodłącznym stylowym elementem kształtowa przestrzeni miejskiej. W dalszym ciągu wzajemna synergia miedzy mostami a zabudową owocuje nowymi atrakcyjnymi konstrukcjami. 


\section{Piśmiennictwo}

[1] Bennis W., 2003: Artist, Leader, and "Neotenic", Journal of Management Inquiry, 12, 1, pp. 81-87. https://doi. org/10.1177/1056492602250521

[2] Bilbaopedia; http://www.bilbaopedia.info/ [03.04.2017]

[3] Calatrava S., 1981: Zur Faltbarkeit von Fachwerken, Thèse de doctorat présentée à ETH, Zurich, OCLC Number: 767238846

[4] FMGB Guggenheim Bilbao Museoa, 2017: https://www.guggenheim-bilbao.eus/en/works/arcos-rojos-arku-gorriak-4/ [22.08.2017]

[5] Gehry F., 2014: https://www.youtube.com/watch?v=ZgqiGk5v9W0 [02.11.2017]; Ruptly TV

[6] Gomez M., Gonzalez S., 2001: A Reply to Beatriz Plaza's 'The Guggenheim-Bilbao Museum Effect', International Journal of Urban and Regional Research, 25, pp. 898-900.

[7] Karas S., 2016: History of Sustainable Bridge Solutions, Chapter 1. of "Structural Bridge Engineering", INTECH. DOI: $10.5772 / 63461$

[8] Plaza B., Haarich S., 2013: The Guggenheim Museum Bilbao: Between Regional Embeddedness and Global Networking, Journal of European Planning Studies, 23, 8, pp. 1456-1475. http://dx.doi.org/10.1080/09654313.2013.817543

[9] UN World Heritage List, 2006 :http://whc.unesco.org/en/list/1217 [22.08.2017]

[10] Zychowska M., 2015: The Architecture of Bridges, Journal of Civil Engineering and Architecture, 9, pp. 554-562. doi: 10.17265/1934-7359/2015.05.007

Summary: The paper concerns the revitalization of the post-industrial city of Bilbao. Revitalization was carried out thanks to modern architectural objects in symbiosis with interesting historical urban buildings. The turning point was the location of the building, designed by Frank Gehry, of the Guggenheim Bilbao Art Museum, and the accompanying facilities in the city center. Bilbao is located along the Nervion River. The new bridges in Bilbao are interesting because of their modernity of form. They adjoin historical bridges in a complementary way. The tourist revival brings millions of visitors to the city, but also other well-known architects who want to leave their mark here, too. One of them was Santiago Calatrawa, who built the pioneering technically and architecturally original footbridge Zubizuri Zubia. The paper also presents some interesting bridges from other cities of the Basque Country. 